\title{
Comment/Commentaire
}

Response to David Hicks "Review of Money Laundering in Canada: Chasing Dirty and Dangerous Dollars.” Canadian Journal of Sociology, 2008 33(3):767-770.

irst, let me thank David Hicks for the effort he took to review our book Money Laundering in Canada: Chasing Dirty and Dangerous Dollars. While he was obviously critical of our book, we acknowledge his right to hold his different views. We would however like to correct some of the statements that Professor Hicks has made and perhaps clarify our own positions. If Professor Hicks is not troubled by the money laundering figures that are bandied about and that grow ever larger with no empirical base, then that is fine. We agree that the figure is large. The size and impact of that amount of cleaned illicit money remains unknown by anyone, anywhere in the world. John Walker, the Australian guru of the attempt to empirically determine these numbers, whom we quote in some detail, has recently embarked on a "global" effort to identify the size; however, even he acknowledged that the task might not be doable. We acknowledge numerous times that criminals should not be allowed to enjoy their ill-gotten gains, but we question the costs of targeting money laundering rather than the predicate offenses that produce those illicit profits.

The RCMP cases have appeared on the Nathanson Centre website, with highlights reported in various articles as Professor Hicks states. The data was collected most specifically for this book and therefore of course the data "does not appear to provide substantive improvement" given that it is the same RCMP case file data. What is surprising is the confusion that Professor Hicks apparently finds with the charts. He mentions in particular the chart on p. 86. As is obvious to anyone studying laundering cases and is obvious from our case analysis, several different laundering mechanisms are typically used in any one police laundering case: i.e., deposit institutions, real estate, and much else. Therefore the implicated economic sectors add up to more than 100 percent. We cannot imagine how the chart could be clearer. For example 59.7 percent of all of the cases involved laundering through the purchase of motor vehicles, but some of these cases also used other sectors of the economy for their laundering needs. A point we emphasize in the text is that 76.5 percent of the cases at some stage involved deposits into financial institutions 
- therefore remaining the most popular "laundering" mechanism (but again, possibly in combination with the use of other sectors).

Professor Hicks is absolutely correct that we seem to have reassigned a new title to FINTRAC - for that we apologize. I suspect we get no credit for the consistency with which we continued to make this error! While conceding that gross error we must question the criticism that Professor Hicks directs towards our discussion of FINTRAC and we must suggest that it is Professor Hicks who is unaware of the procedures that, prior to the coming into force of Bill C-25, law enforcement had to go through in order to obtain anything more than basic information. Our book was well into print before the passing of this new legislation - as Professor Hicks is aware. Professor Hicks states that it is "implausible and illogical" for us to argue that FINTRAC was a "black hole." $\mathrm{He}$ should either re-read our section or consult the Auditor General's report that we reference. The black-hole description was not ours alone. The new Canadian legislation was brought in precisely because FINTRAC was operating as a very expensive black hole! We do not deny that it was Parliament that set out the rules under which FINTRAC could share intelligence. That does not shift valid criticism away from an organization that was at that time not efficient but rather merely suggests that the legislation should have been, and to a limited extent has been, changed.

When we were researching FINTRAC the police and financial institutions were frustrated by the lack of information they were receiving and did not see their input activity as rewarding. The contradictions that Professor Hicks lists are not contradictions at all. Police typically fear that any sharing of information may jeopardize their investigations, especially if they are not expecting to gain from sharing. They told us that because they had no faith in FINTRAC they either submitted the informational reports when they had already decided to close a file or not at all. Likewise the banks were angry at the costs that they incurred by filing reports when they received no information whether their efforts had produced results. As we stated, all of these reactions highlighted the need for changes which were forthcoming.

The final sentence in Professor Hicks's review is particularly baffling. He states that we "avoid critical inquiry into the evidence and the terrain that comprises the mechanisms to tackle money laundering." We have produced one of the most complete analyses of RCMP money laundering cases and the problems involved in "policing" those cases available in any jurisdiction. Other countries have used our analysis to gain insight into the likely vulnerability of their own economic sectors to laundering - with a particular interest in our data regarding the important role that "white collar" professionals play in laundering schemes. The success of FINTRAC is yet to be proven, even with the new legislation. As we all 
learned from the Air India Inquiry in 2007, FINTRAC could not cite a single case where intelligence it gathered has been used in a prosecution related to terrorist financing. The legislation has now changed so we can await improvements to their actual impact. Perhaps the follow-up research would be an excellent project for Professor Hicks.

YORK UNIVERSITY

Margaret E. Beare

\section{Reply to Margaret Beare}

am pleased to offer a reply to Professor Margaret Beare's response to my review of the book Money Laundering in Canada she co-authored with Professor Stephen Schneider. Whilst acknowledging their right to hold views different from my own, I am concerned that Professor Beare appears to have misunderstood the nature and extent of my critique.

Professor Beare argues in the final paragraph of her response: "The final sentence in Professor Hicks's review is particularly baffling. He states that we 'avoid critical inquiry into the evidence and the terrain that comprises the mechanisms to tackle money laundering." "The reader may contrast this with the accurate quotation of what I wrote: "Nevertheless, Beare and Schneider also adopt an undifferentiated approach to the subject matter (post-2000) as they avoid critical inquiry into the evidence and the terrain that comprises the mechanisms to tackle "Money Laundering in Canada" (pp. 769-770, emphasis added).

My disappointment with the post-2000 portion of the book seems to have been misunderstood as applying wholesale to the rest of the work. This has resulted in a curious situation where Professor Beare's response offers a spirited defence against criticisms I did not express. There was not the space in my review or here to explicitly praise each of the components I found helpful, just one of which is the review of RCMP money laundering cases, which offers a particularly helpful and practical contribution to the evidence base. I did not express in my review (as Professor Beare asserts) that I found the charts on money laundering case characteristics to be either confusing or unclear. I did say that there is an issue where categories add up to 381 percent of the "percentage of all cases" (p. 86); this presents a mathematical and analytical challenge of category overlap and I suggested that a typology or typologies could have been helpful to readers in understanding how certain categories overlap.

Professor Beare argues that "Professor Hicks states that it is 'implausible and illogical' for us to argue that FINTRAC was a 'black hole.'" The reader may contrast this with the accurate quotation of the passage in my review: "The authors argue that the information FINTRAC discloses to investigative agencies 'is so brief that it tends to be useless to law 
enforcement' (p. 198). This claim is both implausible and illogical" (p. 769). Professors Beare and Schneider would have made a paradigmatic discovery if financial transactions were proven "useless" to investigations into money laundering! In essence, my complaint was that the authors were blaming (or not standing back from others blaming) FINTRAC for "black holes" that were the result of legislative design that prevented the institution from being more helpful than it has been. Recent Parliamentary legislation will permit more contextual information to accompany a FINTRAC disclosure. This should be helpful to inquiries into known individuals as well as those who were previously unknown to investigators. The assertion that I may be unaware of "production orders" (to which Professor Beare obliquely refers) is decidedly curious given the variety of publicly available documentation that describes this process. With respect to FINTRAC's potential contribution to terrorist financing cases, Professor Beare leaves unaddressed important contextual questions such as how many terrorism-related prosecutions have there been in Canada over time, differential agency responsibilities, and the available responses to such cases?

Professor Beare acknowledges the "gross error" of their relabelling FINTRAC, and laments that I gave them no credit for the consistency of their error. Labelling consistently (in one way throughout) may have deserved some credit, but the reader might compare the variable labelling on pages 19, 44 (correct label), 145, 302 (correct label), and 373 of the book. In this regard, I find it quite charming that Professor Beare offers in her response to "correct" some of the statements expressed in my review.

In their book, Professors Beare and Schneider argue that "Canadian sovereignty should continue to include 'made-in-Canada' laws, policies, and enforcement practices" (p. 314). The Office of the Auditor General of Canada (2004: 6) acknowledges that FINTRAC operates under a "strict legislative framework" with safeguards that are unusual in that most nations allow closer links and information flow between financial intelligence units and law enforcement. The reasons behind this are central to a critical understanding of the functioning of this institution and the anti-money laundering regime within the particular sociolegal context of Canada; the neglect of this dimension is what most disappointed me about the book. If the authors had found it impossible to gather data on or write about the post-2000 situation, they should have stated this explicitly in the text - otherwise, I submit that my critique still stands.

Perhaps in the near future there will be opportunities to continue the previous discussions I have had with Professors Beare and Schneider on these matters. 